Tatjana Spaseska ${ }^{1}$

Aneta Risteska ${ }^{2}$

Gordana Vitanova ${ }^{3}$

Dragica Odzaklieska ${ }^{4}$

Fanka Risteska ${ }^{5}$

Faculty of Economics - Prilep, Macedonia
SCIENTIFIC REVIEW ARTICLE doi:10.5937/ekonomika1602071S Received: April 6, 2016 Accepted: May 11, 2016

\title{
ANALYSIS OF KNOWLEDGE ABOUT CAPITAL MARKET ACTIVITIES IN REPUBLIC OF MACEDONIA
}

\begin{abstract}
Capital market represents the most important and influential segment in the economic policy and practice, with which successful and long-lasting functioning of the complete economical system is realized. Namely, this market offers many possibilities for mobilizing necessary financial resources for financing current and developing work of business entities, and on the other hand, it gives wide choice to the investors for investing free financial resources. Namely, the establishment of a successful stock market in a developing economy can be a major source of economic growth if it provides development finance by channeling domestic savings and attracting foreign investment. However, this objective is not always met, particularly in very small markets where there are barriers to efficient market operations. In that context, the main objective of this research is to analyze the current status of the Macedonian Capital Market (Macedonian Stock Exchange - MSE), the extent of knowledge about Macedonian Stock Exchange as a most important part of the capital market and the sources that promote knowledge about capital market (stock market) activities, also to identify the variables affect the investor's opinion to invest in MSE. In R. Macedonia, the capital market is not developed enough yet, that has a negative influence on business entities financing, and all that affects economic growth and development. Namely, the research carried out in this study has shown that public awareness for the existence and effective functioning of the capital market in the Republic of Macedonia is on a very low level. Altogether, it is observed that there is a long way to go for stock market operations in the Republic of Macedonia but need to get a powerful startup with a very dedicated, investment awareness campaign. The best model of development for Macedonian Stock Exchange is based on the active participation of stock exchange, government and companies inviting investors and creating confidence for secured investment.
\end{abstract}

Key words: capital market, capital market knowledge, Macedonian Stock Exchange, capital market activities, securities

\footnotetext{
${ }^{1}$ tatjanaspaseska@gmail.com

2 a_risteska@yahoo.com

3 vitanova04@yahoo.com

${ }^{4}$ dragicaodzaklieska@yahoo.com

${ }^{5}$ f.risteska@yahoo.com
} 
JEL classification: O16, D53

\title{
АНАЛИЗА ЗНАЊА О АКТИВНОСТИ ТРЖИШТА КАПИТАЛА У РЕПУБЛИЦИ МАКЕДОНИЈИ
}

\begin{abstract}
Апстракт
Тржиште капитала представља најзначајнији и најутищајнији сегмент у економској политици и пракси, са којим се успешно и дуготрајно функционисање комплетног привредног система реализује. Наиме, ово тржиште нуди бројне могућности за мобилизацију потребних финансијских средстава за финансирање текућих и развој рада привредних субјеката, са друге стране, то даје иирок избор инвеститорима за улагање слободних финансијских средстава. Наиме, успостављање успешне берзе за економски развитак може бити главни извор економског раста ако обезбеђује развој финансија за каналисање домаће штедње и привлачење страних инвестиција. Међутим, овај ииль није увек испуњени, нарочито у веома малим тржиштима на којима постоје препреке за ефикасно тржишно пословање. У том контексту, главни ичиь овог истраживања је да се анализира тренутно стање македонског тржишта капитала (Македонска берза - МСE), степена знања о Македонској берзи, као најважнији део тржишта капитала и извора који промовише знања о тржишту капитала (берзи) активности, и да идентификују варијабиле које утичу на мишьење инвеститора за улагање у берзу. У Р. Македонија, тржиште капитала није довољно развијено још, има још негативних утииаја на финансирање привредних субјеката, а све то утиче на економски раст и развој. Наиме, истраживане које спроведено у овој студији је показало да је свест јавности за постојање и ефикасно функиионисање тржишта капитала у Републиии Македонији на веома ниском нивоу. Све у свему, примећено је да постоји дуг пут развоја берзанског пословања у Републици Македонији и да је потребан снажан почетак са врло наменским, инвестииијама паметне кампање. Најбољи модел развоја Македонске берзе је засновано на активном учешћу у берзи, владе и компанија које позивају инвеститоре и стварају поверење за безбедне инвестииије.
\end{abstract}

Кључне речи: тржиште капитала, познавање тржишта капитала, Македонска берза, тржсита капитала активности, хартије од вредности

\section{Introduction}

Financial market is a driver for economic growth and development. In fact, it has different functions, which, if performed effectively, contribute to economic growth and development increasing and living standard improvement.

The financial market has integrated three markets itself, that are very closely connected and conditioned. The capital market, as a segment of the financial market, offers possibilities for mobilizing financial resources for financing current and developing work of the business 
entities, and on the other hand, gives wide choice to the investors for marketing free financial resources.

Capital market authorities, managers, and operators undertake activities fundamental to the growth and development of capital markets in every country that operates a capital market. Their activities include policy formulation, policy implementation, product developments, investor education, and public awareness campaigns, market surveillances, market inspection, as well as offering investor protection. All these activities and many others should lead to improving market performance, development and integrity (Acquah-Sam, 2014, p. 58).

The stock market as a most important segment of the capital market, play a crucial role in mobilizing funds in capital markets. Stock markets provide a platform to investors and borrowers to exchange money by exchanging stocks.

Stock Exchanges represent an organized market form that facilitates - capital raising, trading of listed stocks, product development, increased avenues for investment of individual and institutional investors, free flow of market information and induce better corporate culture and conduct. These features of the capital markets and functioning of the stock exchange are considered vital for developing an efficient financial system that could benefit the real economy (Prasad Bandi, 2014, p.3).

\section{Macedonian Stock Exchange - state and perspective}

Republic of Macedonia successfully established a stock exchange in 1995. The stock exchange was founded as a holding company on a non-profit base, with a start-up capital of 1 million German marks. Although it was established in September 1995, the birth of the Macedonian stock exchange is associated with 28 March 1996, when the stock bell rang for the first time, which announced the official trading start.

The modest volume of transactions on the first date of trading of 25 transactions with 8 different securities, did not weak the feeling that this act was the beginning of new Macedonian economic history. In its initial developing stage, trading on the stock exchange was performed twice a week, on Tuesday and Thursday. The transaction signing was made on "the exchange parquet" in the trading hall via the method of continuous bidding and the model of "market driven by orders".

Starting from 20.01 2001, the Macedonian stock exchange began working on a profit base with start-up capital of 500.000 EUR. Domestic and foreign legal and natural persons can be shareholders on the stock exchange. The property of an individual shareholder is limited to $10 \%$ of the stock exchange principal.

The basic aim of the Macedonian stock exchange was to provide effective, transparent and safe functioning of the organized secondary securities market in R. Macedonia, through a permanent effort of all investors to provide entrance, i.e. exit of financial instruments for trading in the different stock markets at fair market price, to help trade companies to attract new capital for financing their development and to contribute for building confidence into the Macedonian securities market.

The growth of the stock exchange in Republic of Macedonia has been relatively slow, and has especially received a poor response from private companies wishing to raise capital.

In the first several years of the Stock Exchange functioning, (in the period from 1996 to 1998), the Stock Exchange was in the so called "baby" development stage, which was 
characterized by very low activity. Namely, the stock exchange was firstly formed within the early reform processes in 1990s, because it was thought that part of the privatization model would be realized and were realized through the stock exchange. Then follows the second stage, according to many features, very specific development stage (in the period from 1999 to 2004), in which the Stock exchange primary performed the function of indispensable market infrastructure for finishing privatization of public and state capital and consolidation of proprietary structures created by the privatization. That was manifested in a form of domination of block transactions and state auctions into the realized Stock Exchange turnover and absence of companies' voluntary quotation on the stock market. Starting from 2005, new Stock exchange life cycle has been recognized, in which, although the processes of property consolidation in companies have not been finished yet, a component that should be the top aim can be seen - the Macedonian stock exchange AD Skopje to be a place where with a moderate risk, free money of domestic and foreign investors, will be invested and fructified. Significantly increased turnover in 2005, only confirmed that statement.

The last ten years, it can be seen that capacity of the secondary capital market, of the Macedonian stock, has been moving annually as a turnover in all aspects between 100-200 million EUR. The exception are those good years, 2006 and 2007, when the turnover was 500-600 million EUR, and there was one unsuccessful of less than 100 million EUR in 2013. Concerning price movements on the stock within a longer statistical period, in the last decade we can see that there are several cycles-upward aggressive movements from 2005 to 2007, then from 2008 up to 2012, there was a negative price performance in continuity, while in 2013 and 2014 a small improvement and two annual pluses in succession were seen, but it was far away from the previous record levels. The current turnover (2015) and the price levels are not positive at all.

The market capitalization, after the two processes of obligatory quotation (the development of our total market on the offer side, is based on the two projects for obligatory quotation in 2001 and in 2013), i.e., the market value of 115 quoted companies is about 1,6 billion EUR and in relation to GDP is about 18\%. The average indicator for this in EU is $65 \%$, while in USA, UK and Switzerland; the figures go even above 100\%. This is an indicator that shows what kind of enterprise structure and what kind of structure of the financial market, have been created in these 20 years of market economy in the country. It is obvious that there are not many big and quality shareholding companies on the stock exchange, or, there is not appropriate validation of the quoted shareholding companies on the levels as is the average in the EU.

The reasons for such situation can be located in the weak interest of the corporative sector in financing its activities through issue of securities. Namely, in R. Macedonia characteristically is that the business entities provide necessary capital by loans in the banks in the form of long-term credits, and alternative forms of financing, such as financing through issue of securities, are used in a very small volume.

The research carried out by the Centre for economic analyses (Center for Economic Analysis (CEA), 2007, p.6) shows that although 97\% of Macedonian companies have needed additional capital, 76\% have used bank loans for activities financing, and a very small percentage of them used financial resources from issuing corporative shares or bonds and $44 \%$ of them think that they are not ready to collect capital through securities issue.

All a.m. is a consequence of the following factors:

- $\quad$ Not-sufficiently informed management on the advantages offered by financing through securities issue, 
- The business entities are not ready to be public opened - fear of publishing financial statements in public,

- Fear of diminishing the company control, should new shares are issued,

- Not-sufficient education of the public widely concerning the advantages of investing in securities and

- Not-fulfilling the obligations associated with the issued securities by the business entities.

\section{Methodology}

In order to analyze the knowledge about capital market operations, a research was conducted by the way of questionnaires. Questionnaires are the most commonly used instrument in gathering and measuring qualitative data because they present the same questions to all respondents thereby fostering a comparable basis for assessment (AcquahSami, Salami, 2013, p. 193).

The questions were carefully selected in order to get a clearer picture and more quality quantitative analysis of actual conditions concerning the fact how much the Macedonian population is familiar with stock exchange operations.

The questionnaire was realized on a representative sample of 109 respondents from various segments of the literate and working Macedonian population (teachers, administrators, student-workers, petty traders, and professionals in various sectors of the economy).

Purposive and convenience non-probability sampling methods were used to select respondents for the study. These methods were chosen because they are convenient and less costly as they target respondents who can provide relevant information that will help address the issues under consideration (Trochim, 2006). Also, this kind of method of sampling was used because the population is too large to include every individual in the study.

From the quantitative analysis, good conclusions were drawn, on which basis useful recommendations have been given.

\section{Findings and Discussions}

\section{Knowledge and understanding of capital markets activities}

The level of knowledge of the capital markets activities by investors is central to their level of participation. For instance, any investor needs to understand how the market operates, the products and markets and the mathematics that explain it. As new financial products emerge on the national and regional market, investors must understand all of this from an informed perspective (Capital Markets Investors Survey, 2012, p. 24).

However, some of these products are complex and difficult to grasp, especially for financially unsophisticated investors. Accordingly, individual investors need to possess adequate financial literacy and knowledge to make rational allocation decisions to increase their welfare in both the short and long term.

In that context, the main objective of this research is to analyze the knowledge of stock markets activities of the Macedonian population (Macedonian investors). For that reason 
we have designed questions to measure the basic knowledge related to the stock market activities, as well as questions to measure financial knowledge related to financial market instruments, e.g. capital market terminology (stocks, bonds, etc.).

The results from the answers to the questions related with the respondents' knowledge of capital market activities are shown in figure 1. They indicate that 83 respondents, $76 \%$ of the total respondents, had knowledge of capital market activities. On the contrary, 26 respondents, representing $24 \%$ of the respondents, answered that they had no knowledge about capital market activities. This means that majority of respondents have knowledge about capital market activities.

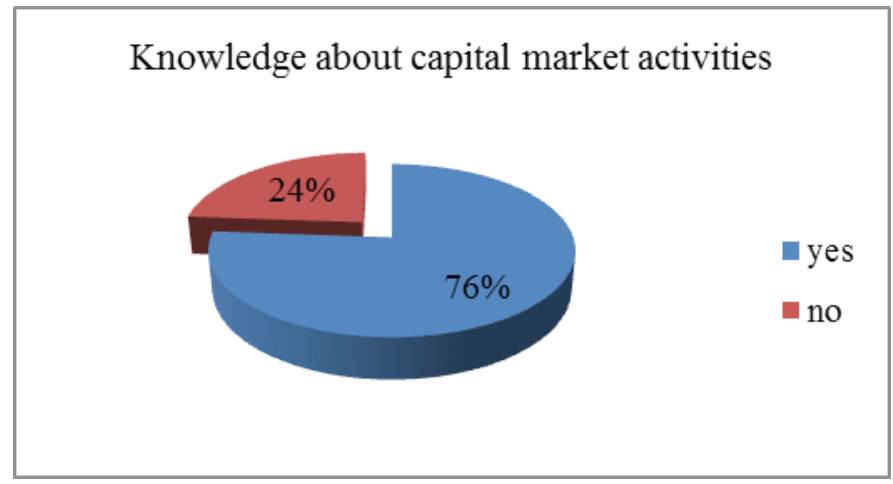

Figure 1: Knowledge about capital market activities

In figure 2 is presented the level of knowledge about capital market activities among respondents who have positive answer on the previous question. According to the processed answers to the question regarding the level of knowledge about capital market activities, as shown in figure no.2, we can conclude that 71 respondents, $86 \%$ of the eighty three (83) respondents who have knowledge about capital market activities, indicated that they have little knowledge about capital market activities. And only twelve 12 respondents, $14 \%$ of the 83 respondents who have knowledge about capital market activities, indicated that they have much knowledge about capital market activities. These results provide evidence for limited financial knowledge about capital market activities. Those who have low financial knowledge are significantly less likely to invest in securities.

One of the reasons about this situation in our country is the low level of financial literacy. Therefore, lack of understanding of economics and finance is a significant deterrent to stock ownership and lack of financial literacy prevents households from participating in the stock market. 


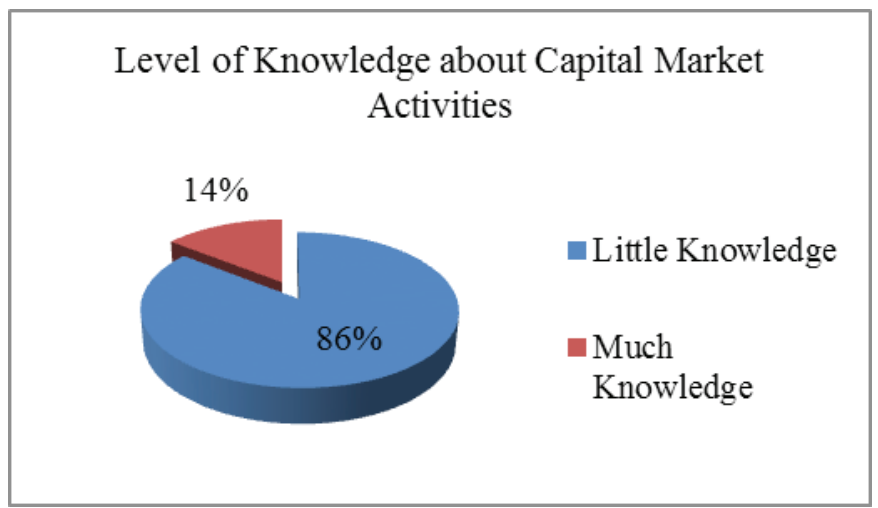

Figure 2: Level of Knowledge about Capital Market Activities and Level of Knowledge about Capital

As noted by Calcagno \& Monticone (2011), the low level of financial literacy in many countries puts households are at risk of sub-optimal financial decisions. Individual respondents who have little knowledge about capital market activities may consequently not know the right kind of financial assets in which to invest, and as a result, may not purchase capital market securities.

The next question in the questionnaire was in correlation with the capital markets' terminologies. Namely, the respondents were asked whether they have ever heard of some capital market terminologies and whether they know the meaning of the selected terminologies. The findings are presented in figure 3 .

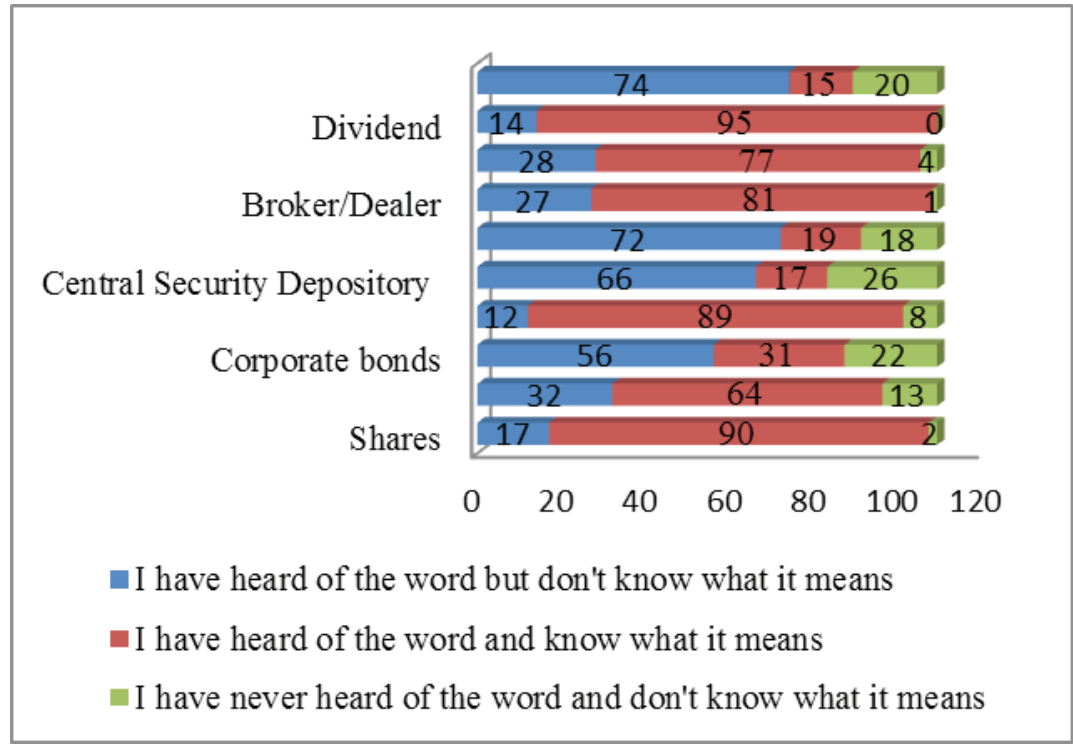

Figure 3: Knowledge about capital markets knowledge 
Most of the respondents stated that they were familiar with the terminology used and that they knew what the terminologies meant. They were generally aware of dividends and shares as reported by $87 \%$ (or 95 ) and $83 \%$ (or 90 ) of the respondents. The two terminologies for which the respondents have minor knowledge are the Central Securities Depository and the Securities and Exchange Commission. Namely, only 16\% (or 17) and 17\% (or 19) of the respondents answer that they know the meaning of the Central Securities Depository and the Securities and Exchange Commission.

\section{Source of knowledge of capital markets activities}

There many factors that influences to assess knowledge about capital markets. For that reasons in this study we analyzed the factors that contribute to respondents' knowledge about capital market activities. Figure 4 presents the various sources where the respondents got information on capital markets from.

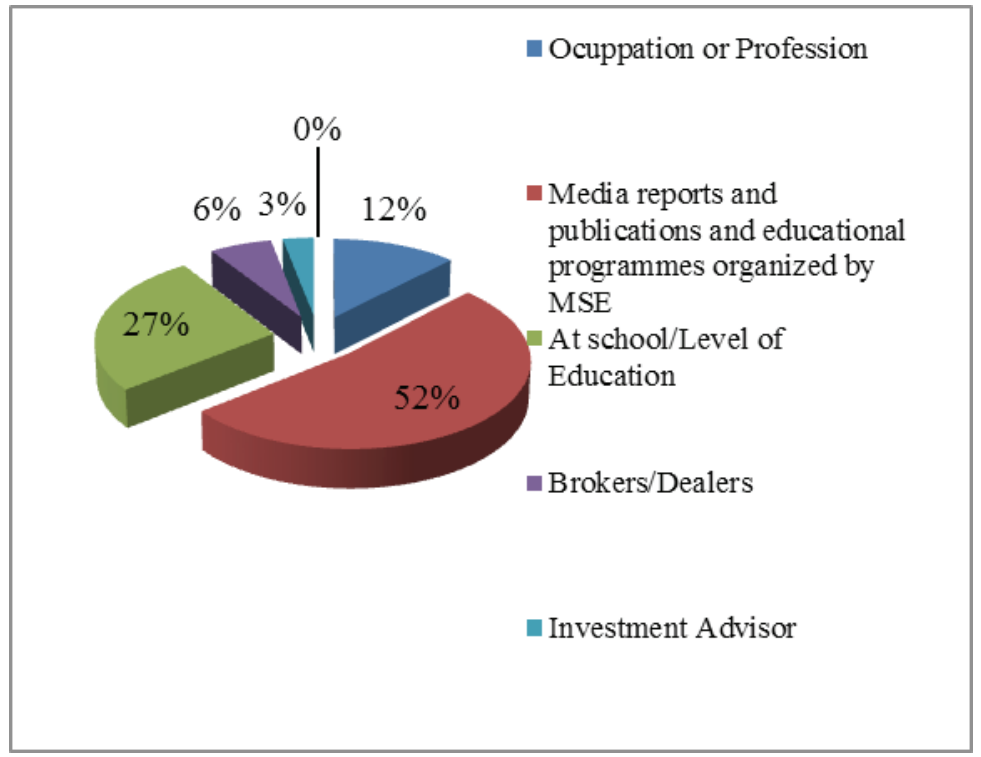

Figure 4: Source of Knowledge of Capital Markets Activities

Ninety eight (98) respondents answered the question on the factors that contributed to their knowledge about capital market activities. Eleven (11) of the 109 respondents who indicated that they had knowledge about capital market activities did not answer the question on the factors that contributed to their knowledge. It could be that they are not aware of the factors that contributed to their knowledge.

It was established that majority of the surveyed respondents (52\%) acquired information about capital markets and related terminologies from media reports and publications and educational programs organized by Macedonian Stock Exchange and market regulators. So, it can be concluded that the most important factor that influences respondents' knowledge about capital market activities is media publications and reports by market regulators and stock exchange. This indicates that these educational and media programs have a very 
positive impact on peoples' knowledge about capital market activities. Accordingly, in the future Macedonian Stock Exchange and market regulators should organize various educational debates and seminars for the managers and investors (especially individual) to increase the knowledge about mobilizing financial resources through issue of securities and about the investment opportunities in financial instruments.

The second major factor that contributed to respondents' knowledge about capital market activities was schooling/level of education. Twenty six (26) respondents, $27 \%$ of the ninety eight (98) respondents acquired knowledge about capital market activities through the courses at school and universities.

By teaching capital market courses in senior high schools, universities, polytechnics, and professional institutions, a significant part of the population becomes aware of the role of the capital market in the lives of individuals and in national development.

The importance of this second factor is supported by Rooij (Rooij et al., 2007), who are of the view that those who were exposed to financial education in high school or in the workplace save more. In other words, as people acquire more knowledge about capital market activities through schooling they are more likely to invest in capital market securities.

Some respondents indicated that their knowledge about capital market activities was influenced by their occupations or professions. This was true for twelve (12) respondents, $12 \%$ of the 98 respondents.

Only 12 respondents answered that they acquired the knowledge from brokers/dealers and investment advisors. Nobody of the respondents acquired knowledge about capital market activities through friends who have experience with investing in securities.

\section{Motivation to invest in capital markets securities}

An investor is any person who commits capital with the expectation of financial returns. Investors utilize investments in order to grow their money and/or provide an income during retirement, such as with an annuity. A wide variety of investment vehicles exist including (but not limited to) stocks, bonds, commodities, mutual funds, exchange-traded funds (ETFs), options, futures, foreign exchange, gold, silver, retirement plans and real estate (http://www.investopedia.com/terms/i/investor.asp). Creation of wealth is the primary objective of investors (http://www.namexijmr.com/demo1/wp-ontent/uploads). Namely, the primary concern of an investor is to minimize risk while maximizing return (http://www. investorwords.com/2630/investor.html). But there many factors that influence on their decisions to invest. Accordingly, this study also sought to find out from respondents with knowledge of capital market activities, the factors that influence their decisions to invest.

The reasons are shown in figure 5. Namely, the respondents were asked what motivated them to invest in capital markets. 


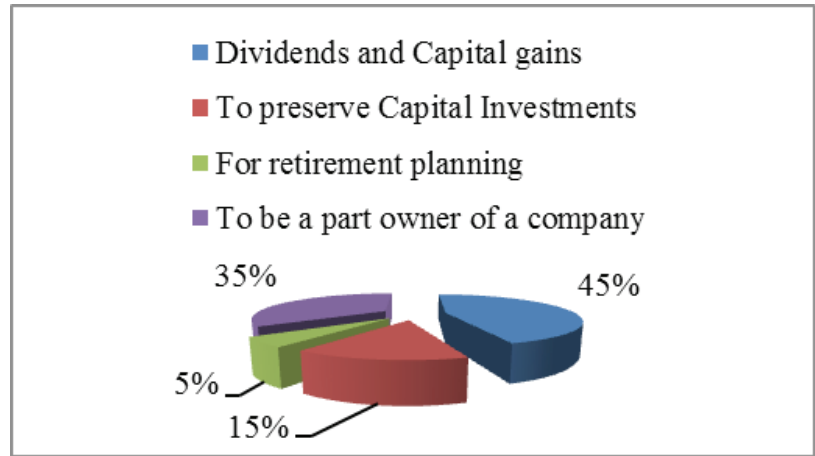

Figure 5: Factors for Investing in Capital Market Securities

The results of the study discover that the most of the investors $(45 \%)$ were motivated by expected dividends or profits to invest in capital markets. Hence, it can be concluded that many potential investors are not aware of the possible benefits obtainable in investing in capital markets and as a result they are not attracted to such investments. Namely, the stock market in Republic of Macedonia is still young and with slow development. In future the markets regulators must accelerate grow through increased incentives that attract key investors. Also, they should informed potential investors how such risks can be minimized in order to increase participation of more investors.

The second major factor for investing in capital market securities was to be a part owner of a company. Thirty four point nine per cents $(35 \%)$ of the one hundred and nine (109) respondents or thirty-eight (38) respondents are motivated to invest in capital market securities to be a part owner of a company.

The third most significant factor respondents invested in capital market securities was because they want to preserve their capital investment. This group constituted $15 \%$ of the respondents or twenty (16) responses. And the last reason respondents purchased capital market securities was to enable them to secure their retirement. Only six (6) respondents, $5 \%$ of the 109 respondents, invested in capital market securities to plan for their retirement.

\section{Reasons respondents do not invest in capital market securities}

Versus the reasons that motivate respondents to invest in capital markets securities, there many reasons that influence on respondents decisions to not invest in it.

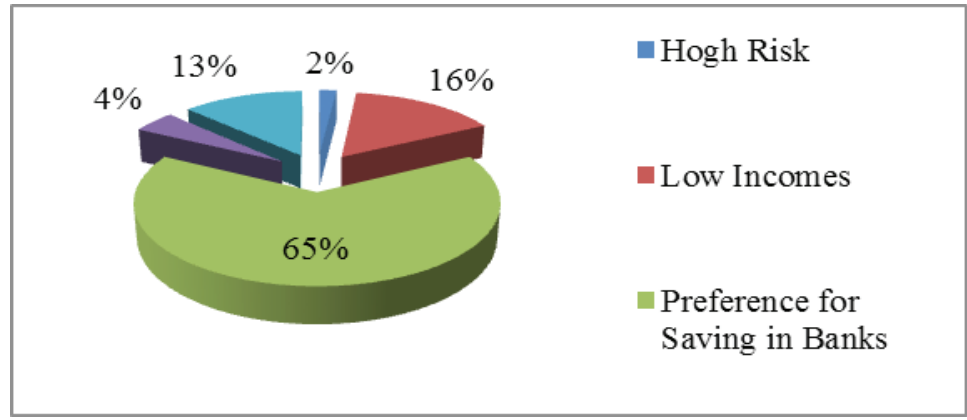

Figure 6: Factors for Not Investing in Capital Market Securities 
The results from the answers to the questions related with the reasons that don't motivate the respondents to invest in securities are shown in figure 6 .

As shown in Figure 6, eighty one (81) of the respondents representing $65 \%$ of the one hundred and nine (109) responses preferred to save with banks. The main reason o this situation in Republic of Macedonia is that both, the population and enterprises are not aware and are not informed about the way of functioning of our capital market and its benefits.

The second reason respondents gave for nonparticipation in capital market activities was low incomes. Namely, $16 \%$ of the one hundred nine (109) respondents chose this reason. This suggests that given increased incomes backed by effective awareness creation programs on capital market securities, appropriate investment advice and the right incentives, a lot of prospective investors could be lured into purchasing capital market securities (Acquah-Sami, Salami, 2013).

The third reason for nonparticipation in capital market is preference for real estate. $13 \%$ of the respondents have positive answer on this reason. This is because Macedonian population has very low level of education and knowledge about how capital market operates and as a consequence they don't trust in Macedonian Stock Exchange.

Very little part of the respondents indicates that lack of interest about workings of the securities $(4 \%)$ and risky to hold $(2 \%)$ is the reason of uninvesting in capital markets.

\section{Conclusion}

In R. Macedonia, the capital market is not developed enough yet, especially the market of long-term securities. This not sufficient development of the long-term securities market has negative influence on the economy, i.e. the business entities are faced with big difficulties when mobilizing financial resources indispensable for financing their work, and all this affects the country growth and development.

Very important factor for providing successful development of the capital market in Republic of Macedonia is existence and functioning of the Stock Exchange. The Macedonian stock exchange should provide effective, transparent and safe functioning of an organized securities market; diversification of the risk with potential investors, via offering large number of different financial instruments; correct allocation of resources and control in management, protection of the investors' interests and instruments, through which the state will meet its financial needs via market resources, not via fiscal and monetary ones.

The Macedonian stock exchange is relatively young institution and has negligible role in financing the business entities. Such situation is due to deep structural obstacles that make difficult its development, among which more important are:

Non-financing companies in R. Macedonia do not show enough interest in financing their activities through issue of shares. This is mainly due to the fact that management teams do not know well the advantages of this kind of financing. Also, it should be noted that managers have some fear that they will lose the managing right and they are also afraid of publishing the company financial statements in public;

- The business entities are not interested in issuing bonds. That is due, mainly, to the absence of expertise for structuring and promoting this kind of securities. On the Macedonian stock exchange, trading is performed only by state bonds from the old foreign currency saving, foreign currency deposits, bonds of R. Macedonia for denationalization, state records and convertible certificates; 
- Not sufficient education of the public widely and business entities about the advantages of investing in securities and financing the businesses through issue of securities;

- $\quad$ Limited offer for financial instruments, in which the investors will direct the free financial resources;

In order to overcome such situations, it is of special importance to increase the Macedonian population and business entities' knowledge for the way of capital market functioning, because just in this place they can, in a very simple and cheap way, provide additional capital for financing their investing projects or for maintaining their current solvency. The survey carried out in this study, has shown that $83 \%$ of the respondents, i.e. $76 \%$, are acquainted with the activities in the capital market, but $86 \%$ of them have answered that their knowledge on these activities, is very low. So, these results indicate that the level of knowledge about capital market is low.

Moreover, the results from the performed analysis show that the advantages of investing in securities are not very well known, not only for the business entities, but for the large part of the public, as well. Due to those reasons, there is need for combined effort from both public and private sectors to sensitize people on how the capital market works, including comparison of capital market investments to conventional investment vehicles and the risks and returns involved in capital market investments. In fact, there is a need for organizing various kinds of seminars and special courses for the people who intend to invest free resources into financial instruments, but also for the employees in the financial institutions dealing with investments in securities, in order to enable them to increase working effectiveness, i.e. to increase the number and the kind of services they offer to their customers.

\section{References}

Acquah-Sami, E. \& Salami, K. (2013). Knowledge and Participation in Capital Market Activities: The Ghanaian Experience. International Journal of Scientific Research in Education, Vol. 6(2), 189-203.

Acquah-Sami, E. (2014). The State of Ghana's Capital Market. Journal of Applied Economics and Business, Vol.2, Issue 3, 55-66.

Apas Consultants Limited (2012) Capital Markets Investors Survey, Apas Consultants Limited, pp.1-65.

Atkinson, A. \& Messy, F. (2012). Measuring Financial Literacy: Results of the OECD / International Network on Financial Education (INFE) Pilot Study. OECD Working Papers on Finance, Insurance and Private Pensions OECD Publishing, No. 15: 1-73. Retrived February 15, 2016, from http://dx.doi.org/10.1787/5k9csfs90fr4-en

Calcagno, R. \& Monticone, C. (2011). Financial literacy and the demand for financial advice. Social Science Research Network, pp.1-47. Retrieved Deecembar 11, 2015 from http://papers.ssrn.com/sol3/papers.cfm?abstract_id=1884813

Center for Economic Analysis (CEA) (2007). Financing via loans or securities issue. Skopje:CEA Publishing, 1-34 
Guiso, L. \& Jappelli, T. (2004). Awareness and stock market participation. Centre for Studies in Economics and Finance (CSEF), Working Paper No. 110: 1-47. Retrieved December 17, 2015, from http://www.csef.it/WP/wp110.pdf.

Guiso, L., Sapienza, P., \& Zingales, L. (2008). Trusting the Stock Market. The Journal of Finance, LXIII (6), 2557-2600.

http://www.investopedia.com/terms/i/investor.asp, accessed on 25 February 2016 http://www.investorwords.com/2630/investor.html, accessed on 25 February 2016 http://www.namexijmr.com/demo1/wpcontent/uploads/2015/06/2013_jan_june_2.pdf7

Lintari, J. (2011). Awareness, Trust and Stock Market Efficiency: The Case of Uganda Securities Market.. Unpublished Master Dissertation, Makerere University, Uganda.

Prasad Bandi, R. (2014, June). Role of Capital Markets and the Stock Exchange. Seminar of Financial Market Development in Myanmar, Nay Pyi Taw, Myanmar Seminar and Briefing Session for Parliamenta, German Ministry of Economic Cooperation and Development (BMZ).

Rooij, V. M., Lusardi, A. \& Alessie, R. (2007). Financial literacy and stock market Participation. National Bureau of Economic Research (NBER), Working Paper No. 13565:1-50. Retrieved January 21, 2016, from http:/www.nber.org/papers/w13565n

Rooij, V., Lusardi, A., \& Alessie, R. (2011). Financial literacy and stock market participation. Journal of Financial Economics, Volume 101, Issue 2:449-472

Trochim, M. K. W. (2006). Non probability sampling. Research Methods Knowledge Base, Retrieved February 10, 2016 from http://www.socialresearchmethods.net/kb/ sampnon.php 